\title{
Sexual Harassment Prevention Training on Personal Safety Skills of Special Needs Students
}

\author{
Risnida Muzdalifah, Muryantinah Mulyo Handayani \\ Profession Psychology Postgraduate Program, Faculty of Psychology, Universitas Airlangga \\ \risnida.muzdalifah@gmail.com
}

\begin{abstract}
This study was conducted to get an overview of the effectiveness of prevention of sexual harassment training on personal safety skills of special needs students. The hypothesis proposed in this study is there is a role of prevention of sexual harassment training on the personal safety skills of special needs. Number of the subjects on this study are 10 people. Effectiveness of training was measured by learning evaluation and learning behavior tools. Learning evaluation was measured by student knowledge before and after training. Learning behavior was measured used checklist to see whether the action plan that has been made is implemented properly. The results showed that there was a role in providing training to prevent sexual harassment on personal safety skills of special needs students.
\end{abstract}

Keywords:sexual harassment, special needs students, training

\section{Introduction}

In recent years, a game known as 'starter' has existed in social media played by the schoolboys of Primary School and Secondary school. The game is performed by the boy called as the victim asked to open his legs widely and another boy as the doer stands in front of the victim stepping his foot on the crotch. The game is considered as accelerating the accelerator of car and producing sound. The doer plays the leg back and forth on the boy genital. During playing the game some other schoolboys witness as the "audiences" and support their friends who play the game. This game was played as well at SMKN 8 Surabaya. Some schoolboys did the game towards one of the students with special needs. The student did not realize and understand about the treatment that he got from his friend. He kept quiet and did not counter the doer, he did nothing. The impact of the incident, the victim didn't want to go to school to study regularly because he was in a big fear that he would be the victim repeatedly in the future.

Although the students considered the action as a game, it obviously had some impacts and is considered as a sexual harassment. O'Barnett, et al (Matlin, 2008) stated that the sexual harassment is an undesired sexual contact. It also has the psychological and physical stress. The sexual harassment does not only deal with the sexual intercourse, but also the other sexual activities such as touching the 
intimate organ with or without clothes. The "starter' game might be categorized as a sexual harassment due to the game directly relates to the intimate organ even still wearing clothes.

Some impacts are found because of the game especially for the teenagers. They are possibly to be the sexual harrasment, anxious, have the low self-esteem, isolate themselves which may lead to the depression and commit the suicide if it has not been overcame (Trickett and Putnam, Howe, 2005). The impact might be more dangerous because the victims of the game are the students with special needs categorized as slow learners. They fail to understand what their friends are doing. Thus, they are not able to reveal what happened on them to others.

One of the solutions to prevent the incident not to happen any longer is by giving the training to transfer the knowledge about the sexual harassment. Bray (2009) explained that the training is a process designed to facilitate the learning process for the participants. The goal of the training is to master the knowledge, skill and behavior which are trained in the training program and is expected to implement in the daily life. Teachers and parents have not understood about the importance of sex education given, especially when the students are invited to do the 'starter' game at school without realizing the negative impact.

A research done by Handayani (2017) proved that the sexual harassment training using personal safety skills effectively worked to prevent the sexual harassment done by the schoolboys of 'starter' game of primary school. Based on the previous research, researcher is interested in conducting another research related to the sexual harassment prevention training towards the students with special needs of SMKN 8 Surabaya.

\section{Research Method}

Ten slow learner students of grade VIII at SMKN 8 Surabaya were selected as the subject. Before doing the training, the intelligence test was administered to ensure that they were at the same level, as slow learners. The FGD (Focus Group Discussion) was also conducted to identify the participant needs to have the training. To know the learning evaluation of the training given was by comparing the pretest and posttest handed over the participants of the training pre and posts the sexual harassment prevention training. The sexual harassment prevention scale was used to seek the effectiveness of the training.

The strategy scale of sexual harassment prevention was arranged based on the Kinnear dimension (2007)in terms of understanding the parts of body which were not allowed to touch, being brave to say no to know the good and bad touch, trusting self-feeling about the right and wrong and reporting to others. The data analysis was Wilcoxon technique because the data did not meet the assumption of normality and homogeneity test.

\section{Result and Duscussion}

The training had been conducted for three days on March 27th, 29 $9^{\text {th }}$ March, and April $2^{\text {nd }} 2018$ at SMKN 8 Surabaya. The training process was directly executed by researcher. The following is the result of Wilcoxon test done during the three days:

Table 1. The result of Wilcoxon test

\begin{tabular}{crrr}
\hline Variable & Day 1 & Day 2 & Day 3 \\
\hline Sexual harassment prevention & Sig : 0,011 & Sig : 0,006 & Sig : 0,015 \\
\hline
\end{tabular}


Based on the test using Wilcoxon technique, it was analyzed that the significant value of three variables was $<0.05$ so that Ho was rejected. Thus, there was significant difference in terms of participants' knowledge related to the sexual harassment of pre and post training. The result was strengthened by Handayani's research (2017) that personal safety skill training was absolutely effective exerted to prevent sexual harassment case.

Furthermore, after being evaluated using the sexual harassment prevention scale, based on the interview conducted with the participants, some progresses were obtained:

Table 2. The Result of Learning Behavior of Students

\begin{tabular}{|c|c|c|}
\hline Indicator & $\begin{array}{l}\text { Check } \\
\text { list }\end{array}$ & Note \\
\hline $\begin{array}{l}\text { Identifying the parts of } \\
\text { body which are not } \\
\text { allowed to touch by } \\
\text { others }\end{array}$ & $\sqrt{ }$ & $\begin{array}{l}\text { Some schoolboys refused to play when they were } \\
\text { invited to play the 'starter' game during the free } \\
\text { period or break time because they knew that } \\
\text { game was including the sexual harassment and } \\
\text { the genital was not allowed to touch by others. }\end{array}$ \\
\hline Being brave to say 'no' & $\sqrt{ }$ & $\begin{array}{l}\text { Some schoolboys refused to play the "starter" } \\
\text { game. Besides that, some schoolgirls who were } \\
\text { starting to fall in love with the boys refused to } \\
\text { send a photo ofheir particular part of body to } \\
\text { send to the boys. }\end{array}$ \\
\hline $\begin{array}{l}\text { Identifying the 'good' } \\
\text { and 'bad' touch }\end{array}$ & $\sqrt{ }$ & $\begin{array}{l}\text { Some students knew that the 'starter' game done } \\
\text { the touch belonged to the bad touching. }\end{array}$ \\
\hline $\begin{array}{l}\text { Trusting the self- } \\
\text { feeling about the right } \\
\text { and wrong }\end{array}$ & $\sqrt{ }$ & $\begin{array}{l}\text { Some schoolgirls trusted their feelings that the } \\
\text { willingness of the boys who asked them to send } \\
\text { their particular part of body was totally wrong. } \\
\text { Therefore, they rejected to do it. }\end{array}$ \\
\hline Reporting & $\sqrt{ }$ & $\begin{array}{l}\text { The students reported the incident to the teacher } \\
\text { about what happened on them so that the escort } \\
\text { teacher followed up the problem. }\end{array}$ \\
\hline
\end{tabular}

Based on the result of the table above, the students with special needs understood that they should report what happened on them. They also understood when they were invited to play the 'starter' game or send the photo of part of body was categorized as the sexual harassment so that they knew what they had to do.

The sexual harassment is the sexual contact or another form of action which is undesired sexually. The psychological or physical stress is usually found in the sexual harassment (O'Barnett et all at Matlin 2008). According to Kinnear (2007), the sexual harassment is not simply a sexual activity. However, touching the genital directly or indirectly includes in the sexual harassment. Kelly (1998) stated that the visual, verbal and physical forms are considered as to sexual harassment. The physical form includes touching, pinching, patting, accidentally nudging, squeezing, getting closer without being desired, and so on. Touching parts of vital organs belongs to physical or behavioral forms categorized of sexual harassment.

Preventing and overcoming sexual harassment towards students with special needs has many effects. Therefore, parents and teachers can know what is happening with their children, parents and 
teachers can provide immediate treatment if there has been sexual harassment, and the child is not afraid to say no if there is someone who tries to harassment him (Kinnear, 2007).

\section{Conclusion}

Based on the result of the study about the sexual harassment prevention training of SMKN 8 Surabaya students with special needs showed that the improvement of knowledge and skill of student with special needs was found after the training. The result of the three days process was the significance value which was less than $0.05(0.011 ; 0.006 ; 0.015<0.005)$. In the implementation and evaluation of the training, it had limitedness where the author did not conduct behavioral evaluations in a more specific quantitative way using frequency (time) so that the participants of the training did not clearly find changes before and after the intervention given. The author only made a checklist when the trainee showed the changes through interviews. It is better for the author made a more specific evaluation sheet.

Suggestions and recommendations that may be given to students with special needs, escort teacher (GPK), and schools are as follows:Students with special needs are expected to know what their friends are doing by asking their friends directly or asking for an explanation to GPK; Students with special needs can tell GPK about the problems they experience, especially in times of interest in the opposite sex; GPK is expected to work with parents to monitor the development of students with special needs both at school and at home.; Schools can provide seminars or training on sexual harassment to all students so that they know many things that fall into the category of sexual harassment other than having sex.

\section{References}

Boland, M.L. (2005). Sexual harassment in the workplace. USA : SPHINX Publishing

Bray, T. (2009). The training design manual: Thee complete practical guide to creating effective and successful training programmes. London : Kogan Page

Goldstein, I.L. \& Ford, J.K. (2002). Training in organization: Needs assessment, development, and evaluation. Belmont, CA: Wadsworth

Handayani, T. (2017). Pencegahan permainan starter melalui mendekatan personal safety skill pada murid sekolah dasar. Journal of Empowerment, 1(1), 61-72

Howe, D. (2005). Child harassment and neglect. New York: Pakgrave Macmillan

Kelly, L. (1988). Surviving sexual violence. Oxford : Basil Blackwell

Kinnear, K.L. (2007). Chilhood sexual harassment. California : ABC CLIO

Kirkpatrick, D.L. (2007). Implementing the four levels : A practical guide for effective evaluation of training programs. California : Berret-Koehler Publishers

Matlin, M.W. (2008). The psychology of women. USA : WADSWORTH CENGAGE Learning

Tony, M. (1998). The handbook of crime and punishment. New York: Oxford University Press 